\title{
Personal capacities needed for transitional co-operation in energy webs between glasshouses and non-horticultural counterparts in The Netherlands - three case studies
}

\author{
Vermeulen, T., Verkerke, W., Vermeulen, P. C. M., Weel, P., Poot, E. \\ Wageningen UR Greenhouse Horticulture \\ P.O. Box 20, 2665 ZG Bleiswijk, the Netherlands
}

Keywords: cross regime cooperation, innovation broker, systems engineering, reflexive design, sustainability

\begin{abstract}
Though technically and economically challenging, heat exchange between glasshouses and non-horticultural counterparts (here called Energy Webs) has shown to be viable based on two operational webs and a number of feasibility studies for different locations within The Netherlands. The organizational and cultural challenges for such cross-regime co-operations however, seem more difficult to breech. So far there are two Energy Webs operational - Greenportkas Venlo (Greenport Glasshouse Venlo) and a Geothermic heat-grid in Pijnacker-Nootdorp. Wageningen UR Glasshouse Horticulture has been involved in multiple initiatives over the past two years to understand and overcome the fixations in the co-operation process.

Researchers performed action-based research by partnering in the two mentioned initiative and a third unsuccessful initiative. This involvement was aimed at coaching the partners in the initiative with a focus on the participating grower, as well as gaining understanding of the issues at hand from a partners' point of view.

Energy webs challenge the growers involved both in their capacity as businessman and in the adaptation of their cultivation strategies that come with the new technology.

Energy webs also challenge the facilitator involved to 1) maintain a network stability given the diversity of actors, 2) manage a transitional design process and 3) manage knowledge mobility and appropriation.
\end{abstract}

\section{INTRODUCTION}

The liberalization of the energy market in 2003 gave opportunity for the glasshouse horticulture sector to became a new player in the energy sector, resulting in over 3030 MWe capacity in CHP $^{1}$ owned by growers in end of 2009 (M. Ruijs pers. comm.). The use of CHP made heat exchange between growers interesting when combined with artificial light - the lamps produce year-round heat so the CHP-heat can be shared with just heat-requiring glasshouses. This led to a number of energy clusters among growers in The Netherlands. At the same time the technique of storing solar heat from glasshouses in aquifers and using it for heating the glasshouses in the winter became available (Van Andel, 2002). 'Harvesting' solar heat has a potential of reducing fossil energy consumption, and with that carbon emission, by $35 \%$. Besides that, in 2006 a Dutch tomato grower drilled a geothermic well, and found it very successful.

These different energy sources and experiences with heat exchange inspired different concepts of heat exchange between glasshouses and non-horticultural parties. We use the term 'energy web' for heat exchange between a horticultural

\footnotetext{
${ }^{1}$ CHP: Combined Heat and Power
} 
partner and non-horticultural users. Electricity exchange or heat exchange between horticultural partners are not considered in this paper. Since 2003 a number of fifteen initiatives of energy webs have started, but only two energy webs are operational. Besides these initiatives, many growers made rough calculations for possibilities in their specific situations (Velden et al., 2007).

In literature and in practice initiatives with the complexity of an energy web rely on external help. The innovation broker (or hired in consultant, change agent or process facilitator) is seen as a crucial factor in transitional processes (Klerkx and Leeuwis, 2008). Complex technology combined with new organizational arrangements and exploitation systems require guidance for a single initiator (grower) to manage it all.

This paper studies the success factors of two dominant characters involved in the energy webs initiatives - the initiator(s) and the process facilitator. Based on the experience of the facilitators (or innovation broker) - the authors of this article - and interviews with parties involved, lessons are drawn from three cases, of which two led to a successful energy web. The article then reflects from insights from knowledge fields of innovation management, business capacities, process facilitation, design processes and transition literature to draw up an overview of tools and capacities used in the cases described. Since the aspects of technique, plant physiology and process aspects have been described earlier by Van Velden et al (2007), Vermeulen et al (2009) and De gelder (2009), this article focuses on 1) the capacities of the involved grower as well as 2) the facilitators' capacities and role interpretation.

\section{CASE DISCRIPTIONS}

\section{Greenportkas Venlo}

In 2005 a group of experts designed a greenhouse concept for optimal energy (KnowHouse B.V., 2004). The concept was based on storage of excess heat from the glasshouse in summer in underground layers called aquifers while during winter this heat can be pumped up again to warm the greenhouse. This concept was then adopted by a grower and with help of the group of experts implemented in Venlo in a 3.5 hectare glasshouse. The energy system was further expanded with a so-called CHP (combined-heat power) installation. This CHP produces electricity and heat.

Inspired by a local installer and a business consultant the existing CHP of the grower was used to heat the neighbouring school and care-facility (a campus with multiple buildings and a small swimming pool), while the excess electricity is sold to the web. The total installation went into operation in 2008. The grower received support for both the optimisation of the new cultivation system and the challenges of heat exchange by Wageningen UR Greenhouse Horticulture. The grower was supported by a peer group of local growers, each with own plans for applying the new knowledge in their own firms. The grower was also involved in the Dutch SynErgy network - a group of growers that had already installed heat storage-systems in their glasshouses (Verkerke and Vermeulen, 2008).

1. The Grower. "I want to keep innovating" says the grower, stating his central motivation. This drive gave him respect of the local officials who were previously planning on out placing his glasshouse to a centralized glasshouse area. The sustainable energy concept the grower presented combined with supplying heat gained him the privilege to stay. But even with the most modern greenhouse the 
grower still keeps on looking for new innovations, for example in new types of glass and new tomato varieties.

The consultant leading the design process for the sustainable greenhouse recognized the growers' innovation drive. "The grower was very eager to learn and could be convinced of different and eventually better energy concepts other than the one he initially had in mind."

Another widely recognized character trait is his durability. "I don't know how he manages to keep on going. The production work itself is very demanding and failing technology and the complexity of the technology make it physically and mentally an enormous challenge." says one of the researchers involved in the project. This enormous challenge was indeed the main concern for the process facilitator. Following advice of the facilitator the grower hired extra technical staff for the tomato production and a consultant to deal with the failing technology.

A third trait was the sensitivity of the grower in approaching the heat consumers in the energy web - the energy exchange with the school and the care facility. The actual broker between the two parties of the energy web- the technician supplying the machinery for the energy exchange - remembers convincing the care facility of the success of the grower as a heat supplier as the main stumble block that had to be taken. The challenges of building trust in this phase were recognized by the consultant that drew up the organizational aspects of the energy web: "crucial in such a process is for both parties to sense each others concerns and fears, without having to express them. This requires sensitivity on both sides." The grower possesses this sensitivity. The end organizational layout however needed a larger institute - in this case the local bank - to guarantee heat supply should the grower go bankrupt.

In terms of corporate strategy, however, the grower had always been focused on a low-cost strategy, supplying a bulk-market with his tomatoes. The buildings were therefore basic, even the facilities where (international) officials had to be welcomed seemed basic if not cheap. This low-cost strategy seemed to conflict with the high-end societal and market interest the company had acquired. The corporate strategy had to over time be transformed to have the total company vision correspond with what the new energy concept and energy exchange had brought: a high investment greenhouse, high end interest and a need for high quality, high end market produce. "It took a while and some 'strategy talk' before the grower understood the company had to change strategy", said the facilitator. Eventually the grower took the advice on board and changed strategy. The change in strategy led to the current production under an added value energy-label while producing higher quality tomato varieties.

2. The Facilitator. The aims of the facilitiation of Greenportkas Venlo were to achieve higher production (estimated at 10\%) and 30\% reduction of energy use. But most of all the facilitation had a direct corporate aspect: "A high producing, energy efficient, but bankrupt company will still make the total sustainability innovation a failure. So I see my role as helping the grower achieve his goals" explained the facilitator. Wageningen UR therefore offered concrete knowledge of plant physiology and energy saving strategies to boost production and reduce costs, and (strongly) suggested hiring of external help for managing the technique. "I felt I had to coach him into less trouble shooting and more getting experienced with the new technology and cropping system."

"I provided simple things such as a blackboard for the grower but also a trust base for his worries and concerns by being an available and reliable factor" says the facilitator. When the immediate (technological) threats were under control, this relation allowed the facilitator to suggest new business strategy as mentioned before, 
introducing new tomato varieties and competence coaching of the grower in terms of presentation and public relations.

The stakeholder relationships were maintained mainly by the facilitator and the accountant. These relations were conducive but also at times tense. Conducive for the subsidies that were provided by a number of stakeholders, but tense in the sense of fitting an innovation process in the framework of a subsidy scheme. Examples of such challenges were the growers' dynamics of striving for (more) innovation, while the subsidy was given for the greenhouse as it was build. Another aspect was the burden of broad communication by the grower - he was asked for many presentations, while he was the single manager, with a small staff consisting of his wife and an administrative help dealing with an at first often failing technology. Likewise the facilitator had to respond to the challenges of a forerunner that uses new technologies and therefore faces new practical and plant physiological challenges.

\section{Geothermic heat-grid (Pijnacker-Nootdorp)}

The Nootdorpseweg is a street in the outskirts of the city of Pijnacker-Nootdorp. The street neighbours a 5.5 hectare pot plant grower, a swimming pool, a sport facility, a fitness centre and a school. In October 2008 the grower initiated talks on possible heat exchange based on CHP (Combined Heat Power). Wageningen UR was asked by the local municipality to join these talks as a process facilitator. The local municipality had direct involvement in the energy web through their subsidy of the swimming pool and exploitation of the sport facility. In March 2009 this led to a combined interest by all parties to calculate the business case and give insight in possible organisational models. By then the grower had shifted his interest from CHP to geothermic energy energy gained by pumping up hot water from deep groundwater layers (see fig. 1). The prospect of using this more sustainable energy source was much welcomed by all parties.

January 2010 the contracts were signed for developing and exploiting an energy web. The web has been active since July 2010.

1. The Grower. As a producer of pot plants, the grower was used to direct contact with his customers. Presentation is therefore very important for his company. "Customers -garden centres, retailers for exclusive shops and decorators - will walk through our glasshouse, picking the plants they desire and listening to the story of this company" says the grower. To boost the story, the company had previously pioneered a sustainability certificate.

In terms of energy, the tropical plants require a steady high level of heat but no artificial light or $\mathrm{CO}_{2}$-supply. Geothermic energy therefore seemed a perfect energy source. From a business point of view geothermic energy gives a predictable energy costs for the years to come, since the investment is known and the annual costs are not very variable. The investments however were too high to be covered by one glasshouse. "We needed additional heat-consumers to make the heat well affordable. These partners needed to be reliable in terms of long term commitment, so, given the economic crisis, the neighbouring glasshouses would not suffice as a primary partner." This argumentation drove the grower to explore options with the swimming pool and the school at 400 meters distance. The energy offer was welcomed by these parties for the reliability of the energy source, the lower costs of energy, the steady energy costs on the long run and its sustainability.

The actual need for mediating between grower and the other parties turned out to be limited. The facilitator remembers: "This first meeting with the alderman, I did the talking - explaining the ambitions, the impact on sustainability, the technical lay- 
out and the chances for 'city branding', basically selling the idea, with the grower sitting next to me. Two weeks later the grower had invited the entire city council to visit his glasshouse and present his ideas." Once the novelty of meeting the officials had worn of, the grower seemed perfectly capable to organise his own network.

The company is run by two cousins and has a 5-person 'desk staff' for planning and financial control. This high level of organisation allowed for one of the owners to invest time in research into the new technology. The estimated time consumption by the grower for establishing the geothermic well and the energy web was two to three work days per week for a period of over two years.

2. The Facilitator. While the grower had established the first contacts with the school and swimming pool, Wageningen UR's facilitator was asked to establish relationship between the grower and local authorities and develop the relationships towards a collective commitment, a business case and further formalisation.

The first meeting with all the foreseen partners in the energy web and municipality representatives was focussed on 1) understanding the motivation of the attendants, 2) listing the technical and economical concerns that had to be addressed in the business case and 3) proposing a process timeline. All were excited about the possible lower energy costs and especially the city council (the civil servants) were very eager to be the first city in The Netherlands to host this sustainable energy concept. All parties readily agreed to have a business case drawn up.

The process of developing a business case led to the insight of the high level of assumptions needed to make the calculations. These assumptions led to debates among experts and with the growers' financial expert. Eventually it required the facilitator to form an opinion and coach the process to a collectively acceptable alternative. "With my background in process management, all of a sudden I had to acquire enough technical and economical insight in energy webs to be able to take such a stand and have the others follow it." the facilitator exclaimed. "And it didn't go smooth."

All parties except for the municipalities representative soon accepted the proposed organisation, exploitation, technical and economical assumptions and eventual outcome of the business case. With the municipality being the biggest heat consumer (via their subsidy on the swimming pool and exploitation of the sport facility) and foreseen co-financier of the distribution pipe, their foreseen investments were substantial. The representing civil servant was primarily concerned about the assumptions in the business case and the way the exploitation was setup. These concerns were presented as genuine doubts the city council would have. However, given the positive attitude of the aldermen, the grower felt these concerns were irrelevant. Further one on one conversation between the facilitator and the civil servant revealed that the concerns were based on fear for possible over-subsidising the project (translating into easy gain for the grower) and the concern about the ownership of the well in a long term perspective - when the glasshouse would be replaced by houses 20-30 years from now. Facilitator: "Given this situation it was hard to reach a trust base with the civil servant - and the council behind him. It took over half a year of presenting data, underpinning assumptions, expressing the growers' good intent and a bit of time pressure to have the civil servants present the case to the council and get approval for the needed co-investment."

\section{Ackerswoude (Pijnacker Nootdorp)}

The foreseen living area of AckersWoude is a new housing development in the city of Pijnacker-Nootdorp. At a conference on sustainable energy for housing 
development organised by the municipality in April 2008, Wageningen UR connected with the development agency for AckersWoude. Together with this development agency Wageningen UR decided to make an inventory of possible heat-exchange concepts with the surrounding glasshouses. We interviewed all the growers within a $1.5 \mathrm{~km}$ radius and found much interest in the possibilities of heat exchange. Based on the different energy strategies among the growers we proposed two concepts: one based on CHP, possibly in a network with multiple growers and one based on heatcooling storage in an aquifer with a single grower. After the second meeting with the different parties it was decided to pursue the latter concept. The first concept seemed too tedious from an organizational perspective on the growers' side, whereas the second concept had the advantage of climate control in the houses by using aquifers. Upon this decision the involved housing corporation and the one grower took over the initiative that Wageningen UR had started, and subsequently asked the facilitator of Wageningen UR to continue coordinating the process.

The initiative had thus started with the municipality, was taken over by Wageningen UR and the housing developer and was adopted by a housing corporation and a grower, at which point Wageningen UR stayed involved as process facilitator.

However the housing corporation's full agendas delayed their research in understanding the technical aspects of the new energy concept. Their enthusiasm was then dampened by institutional challenges for social housing corporations to get return on investment on energy concepts - housing corporations are not allowed to serve as energy provider. This delay caused the grower to doubt the sincerity of the partner. The changing economic climate in late 2008 forced the grower to resort to 'survival mode' with his company, which led to end of the initiative.

1. The Initiators - the housing corporation and the grower. The housing corporation is a relatively small, locally active corporation for social housing with about 40 employees and 2.400 houses and apartments in its care. A number of years ago they had taken over from another corporation a cluster of houses with heat pumps as heat supply as opposed to regular gas based heating. This was their first experience with sustainable energy concepts, and they were eager for more - both for offering lower living expenses for their clients and for developing their sustainability portfolio.

The grower of 8 hectare Anthurium had been looking into sustainable energy concepts long before he joined the initiative. "We see energy concepts with heat storage and heat distribution in the glasshouse as an opportunity for both energy saving and getting a better quality flowers and plants." The grower was interested in joining the initiative for it seemed technically easy to store extra heat and bring a sustainability-gain to another party. The grower was therefore open to serve as heat supplier at marginal profit, provided it could be established without high responsibilities and risks on his side. The Anthurium company was run by a two person management team.

2. The Facilitator. The facilitators' role was to initiate the consortium, starting from scratch. It started by organizing the possible participants and guiding them through a phase of selection to get to the final group, proposing a number of possible energy concepts. After the two main parties took over the initiative, we took on the role of process manager (Acting Director) on behalf of these parties.

The facilitators observed a gap - or wall - of differences in culture, markets and type of customers and dynamics. Some anecdotes of these differences would be:

1. The first meeting between the growers in AckersWoude, the project developer and Housing Corporation took place on a warm day in June. As expected the latter parties were dressed in business outfit. Some of the growers however, 
came straight from their work in the greenhouse, wearing shorts and a dirty tshirt. One can imagine that it took the facilitator some persuasion afterwards to keep the Housing partners involved. The growers had come across as "disorganised" and not as serious partners. (Note: The grower we continued to work did present himself in a suitable outfit).

2. The high innovation speed in greenhouse horticulture means that companies are eager to invest and modernise to keep up with competition. Investment horizons for Dutch growers can roughly be differentiated into the following types:

$\circ$ The investment-horizon of a glasshouse structure is 10 to 15 years.

o Investments in energy concepts or technical concepts need to have a pay back time of maximum $5-10$ years.

- A marketing strategy can oversee about five years due to the fluctuating markets of greenhouse produce.

The decision making and planning for housing development on the other hand is a process of 2-5 years. This process includes political decision making, ground acquisitions, multiple tender procedures for different aspects of the total development, etcetera. The investment horizon stretches to 30 years and even longer for the infrastructure. These companies can handle delays of months and years. A delay of a number of years however, will severely damage the financial position and market position of a grower.

Such differences meant the facilitator spend much time in finding common ground in terms of building understanding between the parties on these investments matters, but also trying to provide for the needs of the parties in terms of progress in the process, insight in the technicalities and economics of the concept and building political will among stakeholders.

The facilitator reflects that "maybe I should have been more involved with the housing corporation to overcome their delays, rather than just spurring them on and drawing the timeline we had collectively agreed on."

\section{REFLECTION ON CASES AND LITERATURE}

\section{Capacities of the initiator/main actor}

Engaging in a transitional niche experiment is a challenging venture for the businessmen involved. The transition towards energy grids requires huge investment, ability to cooperate with new societal partners as well as business partners from different regimes like energy and housing. But for a grower it also involves changing to new production strategies given the new set of technical tools for production, challenging their current knowledge of the production process. Growers were therefore challenged in their capacities in management, risk taking, social engagement as well as new production strategies and market penetration (Veen et al., 2010, Vermeulen et al., 2009). We observe the initiators therefore by their 1) management capacities and 2) skills in adopting new production methods.

1. Management Capacities. To understand the management capacities of growers in such experiments and to be able to coach them in specific areas models have been developed for innovation management (Adams et al., 2006). Such models distinguish phases in an innovation process and the qualities an initiator, manager or innovation team needs to successfully complete these phases and the total innovation. To understand an initiator, manager or grower in the dynamics of transitional 
challenges - here seen as the transition towards sustainability and higher societal involvement (Veen et al., 2010) - we adopted the model of Mirvins and Googins (2009), which describes businessmen in their changing role in corporate citizenship (table 1). This model describes the level of integration within a company on its corporate policies and strategies, values, stakeholder relationship and leadership, while reflecting those aspects to the total societal impact of the company - the level of corporate citizenship. Mirvins and Googins distinguish stage 1 (compliant - a corporate strategy aimed at legal compliance), stage 2 (engaged - a strategy aimed at reputation in the market), stage 3 (innovative - a strategy aimed at building a business case), stage 4 (integrated - a strategy aimed at pursuing ones value proposition) and stage 5 (transforming - a corporate identity aimed at market creation and social change). Similar levels were found in the development of the INK-model, that takes a business perspective, where levels were described as 1) product oriented, 2) processoriented, 3) strategy-oriented, 4) chain oriented and 5) total quality (INK, 2000)

From Mirvins and Googins' interpretation we understand that a grower with ambitions for transitional experiments will need a clear view on the integration of the venture in their values and business strategy. The grower will need social and communicative skills to deal with new partners and political and societal involvement with the initiative. Lastly, the level of (sustainable) innovation achieved will draw attention, making the grower a frontrunner in the sector. Growers therefore need to work on a 'stage 4' of corporate citizenship at the moment of engaging in the project, while being willing to develop towards stage 5. In the cases we qualitatively describe the stage of corporate citizenship found in the growers involved.

Looking at the first case (Greenportkas Venlo) we find an innovative grower that has a clear corporate strategy - low cost production. This fits with a stage 3 corporation. Taking on a value-laden innovation (stage 4) meant for the grower to stretch out in his understanding of sustainability, the societal relevance of his company and relating this back to his corporate strategy. Over time the grower developed into this stage 4 , while occasionally taking the lead in presenting his case to colleagues to challenge them - a stage 5 activity.

The second case was highly initiated by the grower. The grower had a clear corporate strategy and clear market engagement and knew how a sustainable energy concept would boost this strategy further. He was aware of the societal impact of his company through his relationships with customers and his neighbours (he knew some of them personally). This could be interpreted as operating in stage 4 . The grower understood that success of the innovation would put him in the spotlights both in innovation management and sustainability. The grower had knowledge of how to use this to further his company, but did not have any higher purpose in mind in terms of social change (for example among his colleagues).

Also in the third case, the grower was strategically aware of what the innovation could bring his company. The participation in the initiative was clearly a value-driven activity (stage 4). Now that the initiative fell through the grower is looking into other ways to obtain a more sustainable energy concept - through geothermic energy.

Over all the cases we find that a management team of at least two persons was needed to have enough time to research the new opportunities and stay on top of things. In Greenportkas Venlo the grower managed to pull it off, but only few can do that - and it was a high risk for the project. A collapse of the grower would have directly endangered the success of the project. 
2. Ability to Learn. Energy grids are based on new technology or new use of technology in the greenhouses that has immediate impact on production methods. For example the possibility of cooling and de-humidification requires insight in fundamental plant processes and strategies to use the knowledge towards higher yield or better quality. The transitional experiments thus require the grower to be open to learning, but also a (scientific) knowledge creation in fields of plant-physiology and strategies for energy management. The aspect of new production methods was mostly experienced in the first case where many researchers were engaged to coach and monitor towards new cropping strategies. In all cases the growers were open for new insights in production.

\section{Capacities and role of the innovation broker}

So far we have described our involvement as 'the facilitator', having a role in enabling innovation and coaching the parties involved towards implementation, while providing new knowledge when needed. In literature a variety of terms co-exist around these roles. Focusing on the individual of the facilitator (as opposed to the wider body of Wageningen UR with its wider knowledge base), we find the best fit in the term Innovation Broker, being "an organization acting as a member of a network of actors in an industrial sector that is focused neither on the organization nor the implementation of innovations, but on enabling other organizations to innovate" (Winch and Courtney (2007: 751)). Dhanaraj and Parkhe (2006) name the three roles for such an innovation broker - they call it a Hub firm, but Batterink et al 2010 argues their views can be translated to the innovation broker, being 1) managing resource and knowledge mobility, 2) managing value creation and appropriation and 3) managing network stability and development. Their conclusions are based on having an existing network, not regarding the process of network formation. However, the processes at hand the aspect of network formation seemed a central role for the innovation broker. Based on their insight we propose the following three capacity-areas for an innovation broker: 1) network formation and maintaining network stability, 2) managing resource mobility and 3) managing knowledge mobility and appropriation. We describe these roles using insights form Dhanaraj and Parkhe (2006) and adding insights of process facilitation from the arena of 'transition' literature, such as Reflexive Interactive Design (Bos et al., 2009), Multi Level Perspective (Geels, 2002; Raven, 2005), Reflexicity (Loeber, 2003), Communities of Practice (Lesser and Storck, 2001), transition management (Rotmans, 2006) and process facilitation (Vermeulen et al., 2009).

1. Capacity area 1: network formation and stability. How to design a network? How to steer it to effectiveness? And how to maintain network stability? From the different perspectives on these questions we found most support in the following bodies of literature:

- An aspect of transition management is to understand the phase the transition it is in, be it a new technology in a stable regime (dominating regime players see no reason for change) or a well advanced technology in an unstable regime (external pressure on the regime leads to an openness for change) (Raven, 2005). In the case of energy webs we saw it as a relatively new technology in a stable regime. The literature predicts in this case an opposition from the current regime players - in our case the energy companies and legislation. This - and experiences from energy webs elsewhere in The Netherlands - led us to not include energy companies in our networks. 
- Understanding interests of parties is an other driver for network formation (Van de Wiel et al., 2010). What motivates the parties and the individuals involved to join? Are these motivations conducive and can they be aligned? If not the network could become unstable.

- Are individuals sensitive towards each others context and background? We draw on this predominantly from the experiences in cases Greenportkas Venlo en AckersWoude, where sensitivity and mutual understanding was seen as crucial for cooperation. (see description case 3; Vermeulen et al., 2009).

- Network stability is greatly increased by drawing up scenarios of the future having a vision to strive for - and setting milestones in the process to have all parties experience progress (Dhanaraj and Parkhe, 2006)

In all cases but the AckersWoude case the networks provided sufficiently stable to achieve success. In AckersWoude the motivators of the partners seemed not strong enough to overcome institutional challenges on the side of the housing corporation, while the grower chose different pathways when challenged with delays. This network seemed to have lacked collective experience in designing the common cause and capacity on the side of the housing corporation to overcome institutional challenges.

2. Capacity area 2: Managing resource mobility. In the first place this capacity deals with general project management - managing budgets, human and nonhuman resources, defining milestones and deadlines. For transitional processes these managerial capacities however are stretched since the end goal is often not clearly defined (Rotmans, 2006, Loeber and Vermeulen, 2010). These often abstractly described project goals require higher levels of reflexivity on the progress. Tools of the knowledge area of Monitoring and Evaluation can be used for enhancing an innovation brokers' (and the innovation networks') level of reflexivity, tools like learning history (Loeber, 2003), Reflexive Process Monitoring (Mierlo et al., 2010) can be of value.

Besides the aspect of project management, recourse mobility can also be viewed by its purpose: the (technical) engineering process. In approaches of Systems Engineering (Kroonenberg and Siers, 1999; Henten et al., 2006) and Reflexive Interactive Design (Bram Bos, 2009) resource and knowledge mobility is presented in terms of R\&D-management and process leadership. Management is generally identified in terms of time, targets and recourses. Process leadership on the other hand includes understanding the expertise and network involvement required in the different phases of the design process. The design process is generally seen in three phases: first stakeholder engagement to draw up vision and criteria for the innovation (stakeholders are seen as users, society and experts), then the technical design including drawing up the technical functions and applying creativity to develop alternative forms and thirdly the implementation where the vision and system description needs to translate to a business case and eventually knots and bolts. In these processes reflexivity is needed when the design goals are not clearly defined and in the process it self, for example in developing new system functions that lead to higher levels of sustainability.

Based on these interpretations the facilitator's capability of 'managing resource mobility' is valued by:

1) his or her understanding of the design process,

2) general qualities in project management and

3) ability to organise (self)reflexivity. 
In the cases described, the design phase was crucial in the cases of Greenportkas Venlo and the geothermic heat-grid (the latter being more focused on organizational design through developing the business case). The third case never actually entered the technical design process. General project management was found to be lacking in the case of the geothermic heat-grid for budget reasons (the innovation broker was financially undervalued, as noted in more cases by Klerkx and Leeuwis (2008). However, the effort of the grower prevented the energy web from collapsing. Self reflexivity was organised in all cases through informal meetings with colleagues and with parties involved and in the Greenport Venlo-case though an interview series with all stakeholders performed by an outsider.

\section{Capacity area 3: managing knowledge mobility and appropriation.}

Dhanaraj and Parkhe (2006) specify this aspect by naming the three processes involved: 1) knowledge absorption (the ability to identify, assimilate and exploit knowledge form the environment), 2) network identification (reinforcing a common identity among network members) and 3) interorganisational socialisation (formal and informal linkage among network members). In 'transition'-literature however, the aspect of knowledge mobility through networks is seen as the capability of a facilitator to stimulate reflexivity (or $2^{\text {nd }}$ order learning), using process tools such as network formation or Communities of Practice (Loeber, 2003). Reflexivity can be further specified as "an act of self-reference where examination or action 'bends back on', refers to, and affects the entity instigating the action or examination". Tools that seemed helpful were:

- Learning History in which the participants periodically evaluate and 'harvest' the lessons learned, both the technical and the changes in thinking. These sessions can be done annually or at the moments of achieving a milestone in the process.

- Communities of Practice are defined as "groups whose members regularly engage in sharing and learning, based on common interests" (Lesser and Storck, 2001).

- Mobility of knowledge within a network promotes value creation. Yet the innovation broker must take the next step to ensure that the value created is distributed equally and is perceived as such by network members (Dhanaraj and Parkhe, 2006). Because such distribution is often complicated by problems of free riding and opportunism, appropriability is a central concern in the economics of innovation. Preventing opportunism can be done by building trust in the organisational layout: clear communication, clear sanctioning, procedural justice when companies have parallel R\&Dtrajectories and joint asset ownership of intellectual property.

Only in the case of Greenportkas Venlo a formal Community of Practice was established. In all cases the knowledge creation was heavily dependant on input from outside parties, being installers, consultants and researchers. The facilitation by Wageningen UR was then aimed at having the growers adopt these (sometimes conflicting) insights. Using personal skills in 'formal and informal linkage' seemed the most used aspect of managing knowledge mobility in the cases described - in all cases with success. Facilitators would describe this as personal relationships, being present and available, understanding power relationships and the role knowledge within these relationships and communicating the data generated to the partners to strengthen or alter their perspective.

\section{IN CONCLUSION}


We propose a set of reflective tools for facilitators embarking on a transitional process like an energy web to help them understand their own challenges and pitfalls and to be able to coach the initiators towards success. The aspects introduced for understanding the needed capacity of growers and facilitators to successfully complete energy webs were based on literature as well as experiences of the facilitators involved. The reflective tools involve:

Initiator/Growers' capacities

- Management capacities: The Levels of Corporate Citizenship as described by Mirvis and Googins (2009) as well as the business perspective as taken by the INK-model are helpful to understand the business and societal engagementchallenges that lie ahead for the grower. The levels 3 (innovative and strategyoriented) seemed to be the base level for taking on such a project, whereas the grower needs a willingness to develop to level 4 (integrated and chain oriented) or even 5 (transforming and total quality oriented).

- Ability to learn: As we didn't experience challenges at this area the value of this capacity (or characteristic) can be under estimated. A transitional project however, will always include learning by all partners. Openness towards learning and a capacity to learn and change remains vital.

Facilitators' capacities:

○ Network formation and maintaining network stability. The formation of network is done by management decisions but is probably more dependent on randomness of which parties are willing to join. Especially in spatially oriented projects as energy webs one has only limited flexibility in selecting partners. Once the parties are deemed to have enough capacity to indeed finish the project successfully it is up to the facilitator to achieve the goals through the partners. We gave a number of aspects to include when selecting partners and designing the process.

- Managing resource mobility. This is presented as 1) his or her understanding of the design process, 2) general qualities in project management and 3) ability to organise (self)reflexivity.

- Managing knowledge mobility and appropriation. In our cases this capacity was mostly expressed through personal skills in 'formal and informal linkage'.

The cases, even though all focused at designing energy webs, differed widely in the attention the facilitator had to spend at different aspects:

- Greenport Venlo: managing the complexity of the technique through coaching and equipping the grower

- Geothermic energy-grid: drawing up an acceptable business case that would convince policy makers and investors given the high level of uncertainty. Facilitation is this case was further hampered by too small financial support for the facilitator given the task asked.

- AckersWoude: building understanding between parties from two culturally different regimes: the horticultural and the housing regime

\section{References:}

Adams, R., Bessant, J. and Phelps, R. 2006. Innovation management measurement: review. International Journal of Management Reviews, 8: 21-47.

doi: $10.1111 / \mathrm{j} .1468-2370.2006 .00119 . x$ 
Andel. E. van. 2002. Concept voor een energieproducerende kas. Startnotitie voor een innovatietraject. InnovatieNetwerk Groene Ruimte en Agroculuster, Stichting Innovatie Glastuinbouw. Rapportnr 02.2.015. isbn 90-5059-158-2

Batterink, M. H., Wubben, E. F. M., K., Laurens and Omta, S. W. F.(2010) 'Orchestrating innovation networks: The case of innovation brokers in the agrifood sector', Entrepreneurship \& Regional Development, 22: 1, 47 — 76

Bos, A.P.; Groot Koerkamp, P.W.G.; Gosselink, J.M.J.; Bokma, S. 2009. Reflexive interactive design and its application in a project on sustainable dairy husbandry systems. Outlook on Agriculture 38 (2). - p. 137 - 145.

Dhanaraj, C and Parkhe, A., 2006. Orchestrating innovation networks. Academy of Management Review 2006, Vol. 31, No. 3, 659-669.

Geels, F.W. 2002. Understanding the dynamics of technological transistions. Thesis, Twente University, Enschede

Gelder, A. de. 2009. Climate control by humidification and cooling in (semi-)closed greenhouses with sweet pepper. Québec City, Canada : Wageningen UR Greenhouse Horticulture, International Symposium on High Technology for Greenhouse Systems GreenSys2009, 2009-06-16/ 2009-06-19

INK, 2000, Gids voor toepassing van het INK-managementmodel, Instituut Nederlandse Kwaliteit, 's Hertogenbosch, September 2000, 2 engewijzigde druk

Klerkx, L. and C. Leeuwis. 2008. Establishment and embedding of innovation brokers at different innovation system levels: insights from the Dutch agricultural sector. Technological Forecasting \& Social Change.

Doi:10.1016/j.tehcfore.2008.10.001

KnowHouse B.V. 2004. Glastuinbouw van de toekomst, nu - van mogelijkheid naar werkelijkheid technisch voorontwerp. Horst, Know House B.V.. www.knowhouse.info

Kroonenberg, H.H. and van den Siers, F.J. 1999, Methodisch ontwerpen, ontwerpmethoden, voorbeelden, cases, oefeningen. ISBN 9011045297. Educatieve Partners Nederland BV, Houten, the Netherlands.

Lesser, L.E.; Storck, J. 2001. Communities of Practice and organizational performance. 40. IBM Systems Journal.

Loeber, A., 2003 - Learning processes at group level. [First and second order reflection among participants in the NIDO programme 'From Financial to Sustainable Profit.'] In: J. Cramer, Learning about Corporate Social Responsibility. The Dutch Experience. Amsterdam etc.: IOS Press. pp. 83-99.

Loeber A., and Vermeulen, T. 2010. The art of 'doing' sustainable agricultural innovation: approaches and attitudes to facilitating transitional projects. Conference paper International workshop on System Innovations, Knowledge Regimes, and Design Practices towards Sustainable Agriculture. Lelystad, The Netherlands, 16-18 June 2010

Mierlo, B.C. van; Leeuwis, C.; Smits, R.; Klein Woolthuis, R. 2010. Learning towards system innovation: Evaluating a systemic instrument. Technological Forecasting and Social Change 77 (2). - p. 318 - 334.

Mirvis, P.H., and B.K. Googins, 2009. Movint to next generation of corporate citizenship. CCCD - Centrum für Corporate Citizenship Deutschland. www.cccdeutschland.org

Raven, R.J.M. 2005. Strategic Niche Management for Biomass - A comparative study 
in the experimental introduction of bioenergy technologies in the Netherlands and Denmark. Eindhoven Technische Universiteit Eindhoven - proefschrift. ISBN. 90- 386-0285-5. NUR 973

Rotmans, J. 2006. Transitiemanagement - sleutel voor een duurzame samenleving. Van Gorcum. Tweede druk. ISBN 9023239946

Van Henten, E.J., Bakker, J.C., Marcelis, L.F.M., van 't Ooster, A., Dekker, E., Stanghellini, C., Vanthoor, B., van Randeraat B. and Westra, J. 2006. The Adaptive Greenhouse - an Integrated Systems Approach to Developing Protected Cultivation Systems. Acta Hort. 718:399-406.

Veen E., Vermeulen P., Schoorlemmer H. 2010. Verbindingen tussen agrarisch ondernemer en burger. Een verkennend onderzoek waarin verschillende typen verbindingen worden herkend en hun kenmerken benoemd. Wageningen UR. Intern werkdocument. In printing

Velden N. van der, M. Raaphorst, C. Reijnders, G.J. Swinkels, J. Buurma 2007. Warmtelevering door de glastuinbouw; quick scan Agriport A7.

Verkerke, W., T. Vermeulen, 2008. Grower delivers heat to external partners. Fruit \& Veg Tech 8.3.

Ir. T. (Tycho) Vermeulen, Dr. W. (Wouter) Verkerke and Ir. E. H. (Eric) Poot. 2009. Role of a Change Actor in the initial phase of transitional projects - Three case studies of energy webs between glasshouses and non-horticultural counterparts in The Netherlands. Conference paper First European Conference on Sustainability Transitions. KSI Conference, Amsterdam 4th to 6th June 2009

Wiel, G. Van De, Wijnands, F. en J. de Bie. 2007. Invloed zonder macht.

Stakeholdermanagement als aanpak voor verduurzaming in de landbouwsector. In print

Winch, G. M., and R. Courtney. 2007. The organization of innovation brokers: An international review. Technology Analysis \& Strategic Management, 19(6), 747-763. 


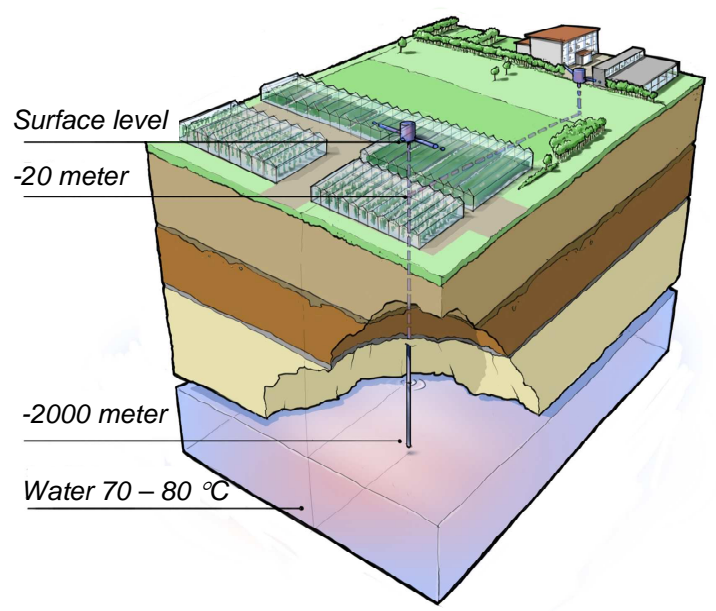

Fig. 1: Impression of geothermic well heating a glasshouse, school and sports facilities.

Table 1: Levels of corporate citizenship (Mirvins and Googins, 2009)

\begin{tabular}{|c|c|c|c|c|c|c|}
\hline & & $\begin{array}{l}\text { Stage } 1 \\
\text { compliant }\end{array}$ & $\begin{array}{l}\text { Stage } 2 \\
\text { engaged }\end{array}$ & $\begin{array}{l}\text { Stage 3 } \\
\text { innovative }\end{array}$ & $\begin{array}{l}\text { Stage } 4 \\
\text { integrated }\end{array}$ & $\begin{array}{l}\text { Stage } 5 \\
\text { Transforming }\end{array}$ \\
\hline \multirow{3}{*}{$\begin{array}{l}\text { Relating to } \\
\text { society: } \\
\text { Outside In } \\
\end{array}$} & Issue management & Defensive & Reactive, Policies & $\begin{array}{l}\text { Responsive, } \\
\text { Programs }\end{array}$ & $\begin{array}{l}\text { Pro-Active, } \\
\text { Systems }\end{array}$ & Defining \\
\hline & $\begin{array}{l}\text { Stakeholder } \\
\text { relationships }\end{array}$ & Unilateral & Interactive & $\begin{array}{l}\text { Mutual } \\
\text { influence }\end{array}$ & Partnership & $\begin{array}{l}\text { Multi- } \\
\text { organization } \\
\text { alliances }\end{array}$ \\
\hline & Transparency & Flank protection & Public relations & $\begin{array}{l}\text { Public } \\
\text { reporting }\end{array}$ & Assurance & Full exposure \\
\hline \multirow[t]{4}{*}{$\begin{array}{l}\text { Relating to } \\
\text { society: } \\
\text { Inside Out } \\
\end{array}$} & Citizenship concept & $\begin{array}{l}\text { Jobs, profits \& } \\
\text { taxes }\end{array}$ & $\begin{array}{l}\text { Philanthropy, } \\
\text { environmental } \\
\text { protection }\end{array}$ & $\begin{array}{l}\text { Responsible to } \\
\text { stakeholders }\end{array}$ & $\begin{array}{l}\text { Sustainability or } \\
\text { triple bottom } \\
\text { line }\end{array}$ & $\begin{array}{l}\text { Change the } \\
\text { game }\end{array}$ \\
\hline & Strategic intent & $\begin{array}{l}\text { Legal } \\
\text { compliance }\end{array}$ & Reputation & Business case & $\begin{array}{l}\text { Value } \\
\text { proposition }\end{array}$ & $\begin{array}{l}\text { Market creation } \\
\text { of social change }\end{array}$ \\
\hline & Leadership & $\begin{array}{l}\text { Lip service, out } \\
\text { of touch }\end{array}$ & $\begin{array}{l}\text { Supporter, in the } \\
\text { loop }\end{array}$ & $\begin{array}{l}\text { Steward, on } \\
\text { top of it }\end{array}$ & $\begin{array}{l}\text { Champion, in } \\
\text { front of it }\end{array}$ & $\begin{array}{l}\text { Visionary, ahead } \\
\text { of the pack }\end{array}$ \\
\hline & Structure & $\begin{array}{ll}\text { Marginal: } & \text { staff } \\
\text { driven } & \end{array}$ & $\begin{array}{l}\text { Functional } \\
\text { ownership }\end{array}$ & $\begin{array}{l}\text { Cross- } \\
\text { functional } \\
\text { coordination }\end{array}$ & $\begin{array}{l}\text { Organizational } \\
\text { alignment }\end{array}$ & $\begin{array}{l}\text { Mainstream: } \\
\text { business driven }\end{array}$ \\
\hline
\end{tabular}

